\title{
A CONSTRUÇÃO DO HIPERTEXTO EM DICIONÁRIOS ESCOLARES INFANTIS
}

\author{
THE CONSTRUCTION OF HYPERTEXT IN \\ CHILDREN SCHOOL DICTIONARIES
}

Rodrigo Alves Silva ${ }^{161}$

Yana Liss Soares Gomes ${ }^{162}$

\begin{abstract}
RESUMO: Este trabalho analisou a hipertextualidade em dicionários escolares infantis avaliados pelo PNLD. Para tanto, observou-se, na construçấo do hipertexto, os elementos multimodais, principalmente os boxes que contêm outros gêneros textuais. Este trabalho partiu do pressuposto de que o hipertexto está também presente no texto impresso e náo é exclusivo do texto virtual, baseado em Koch (2009) e Coscarelli (2009). Além disso, utilizou-se dos conceitos de multimodalidade para a análise das páginas dos dicionários. O corpus de análise é composto por dois dicionários escolares: Saraiva Júnior: dicionário da língua portuguesa ilustrado (2009) e Saraiva infantil de A a Z: dicionário da língua portuguesa ilustrado (2012). Uma análise prévia permitiu concluir que esses dicionários possuem recursos multimodais (como imagens, boxes com poemas, adivinhaçóes etc.) que ajudam a tornar esses materiais objetos hipertextuais, pois as informaçôes nâo ficam apenas a cargo dos verbetes, mas também estăo presentes nos demais elementos que os circundam.
\end{abstract}

Palavras-chave: Hipertexto; multimodalidade; dicionários escolares.

ABSTRACT: This study analyzed the hypertextuality in children school dictionaries evaluated by PNLD. Therefore, it was observed in the construction of hypertext, multimodal elements, especially the boxes containing other textual genres. This work began with the assumption that the hypertext is also present in the printed text and is not unique to virtual text, based on Koch (2009) and Coscarelli (2009). In:addition, we used the concept of multimodality for analyzing pages of dictionaries. The analysis corpus consists of two school dictionaries: Saraiva Junior: Illustrated Dictionary Portuguese (2009) and Children Saraiva of A to Z: Illustrated Dictionary Portuguese (2012). A preliminary analysis concluded that these dictionaries have multimodal resources (such as images, boxes with poems, riddles etc.) that help make these

161 Mestrando em Letras pela Universidade Estadual do Piauí (Teresina), graduado em Letras-Português pela mesma instituiçăo. Correio Eletrônico: rodrigoalvessilva@hotmail.com.br

162 Pós-doutoranda e bolsista PNPD no Programa de Mestrado em Letras da Universidade Federal do Piauí (UFPI-Teresina). Doutora em Estudos Linguísticos pelo Programa de Pós-Graduaçâo em Estudos Linguísticos (POSLIN) da Universidade Federal de Minas Gerais (UFMG). Correio Eletrônico: profletras2007@hotmail.com 
material hypertextual objects, because information are not only in the entries, but are also present in other elements that surround them.

Keywords: Hypertext; multimodality; school dictionaries.

\section{INTRODUÇÃO}

Este trabalho analisa a hipertextualidade em dicionários escolares voltados para alunos do primeiro ciclo do Ensino Fundamental (do segundo ao quinto ano). Esses dicionários sâo classificados pelo Programa Nacional do Livro Didático (PNLD) Dicionários de 2006 e 2012 como dicionários escolares do tipo $2^{163}$ (RANGEL; BAGNO, 2006; BRASIL, 2012).

Considerando que esses materiais didáticos contêm ilustraçōes que ajudam a entender um verbete, questiona-se: quais os recursos utilizados pelos autores para a construçâo do hipertexto e quais os gêneros textuais que compóem essa construçâo de hipertexto?

Sendo assim, tem-se como objetivo principal analisar o hipertexto em dois dicionários escolares avaliados pelo PNLD. Para tanto, descreve-se como os verbetes se relacionam aos elementos multimodais (imagens e ilustraçōes), principalmente aos boxes que contêm outros textos, bem como identificar os principais gêneros textuais presentes no hipertexto dos dois dicionários analisados.

Este trabalho parte do pressuposto de que o hipertexto está presente no texto impresso e năo é exclusivo do ambiente virtual, baseado em Koch (2009) e Coscarelli (2009). Sáo utilizados de Mayer (2001) e Teixeira (2008) alguns conceitos referentes à multimodalidade para compreender o papel das imagens e ilustraçôes nas páginas dos dicionários.

Nesse sentido, destaca-se a relevância deste estudo, pois se concebem os materiais didáticos - livros e dicionários - como instrumentos importantes no aprendizado da leitura e da escrita. Sendo assim, os resultados desta pesquisa podem contribuir com os estudos da área da Linguística Textual, sobretudo no contexto pedagógico, uma vez que investiga dicionários escolares, permeado de diferentes gêneros textuais.

\section{TEXTO E HIPERTEXTO}

O conceito de texto tem mudado ao longo do tempo, desde o surgimento da Linguística Textual, na década de 1960, até os estudos mais recentes. Cada concepçâo de texto orienta os estudos de diferentes maneiras, ora enfatizando as relaçôes entre as frases, ora observando os elementos que fazem do texto um texto etc. ${ }^{164}$

163 O PNLD - Dicionários classifica os dicionários em quatro tipos: tipo 1, tipo 2, tipo 3 e tipo 4. Essa classificaçấo tem como principais critérios o número de verbetes no dicionário e o público-alvo. Essa classificaçăo é discutida com mais detalhes em seçâo posterior.

164 Nâo se pretende, neste tópico, fazer o rastreamento histórico da Linguística Textual. Para o estudo do tema, cf. Fávero e Koch (2008). 
A concepçâo adotada neste trabalho é a de texto como lugar de interaçâo entre autor, texto e leitor, na qual se entende que o leitor interage com o autor para a construçâo de sentido, ativando seus conhecimentos de mundo e preenchendo as lacunas existentes no texto (KOCH, 2009). Nessa perspectiva, o sentido do texto é construído em um processo de interaçăo entre autor, texto e leitor. Além disso, acredita-se que "[...] todo texto constitui uma proposta de sentidos múltiplos e năo de um único sentido, e que todo texto é plurilinear na sua construçăo" (KOCH, 2009, p. 61). Em funçăo disso, a autora citada afirma que todo texto é um hipertexto. Isso porque o próprio processo de construçăo de um texto se dá a partir de outros textos, como também o processo de leitura, que é feito por meio de ativaçăo de conhecimentos prévios advindos nâo só de experiências vivenciadas, mas também das leituras de outros textos. Sendo assim, um texto, seja em seu processo de produçấo ou de leitura, sempre remete a outros textos.

Os textos podem ser de naturezas diversas e com propósitos distintos. Eles circulam na sociedade e baseiam a maioria das atividades humanas. Esses textos sáo chamados de gêneros textuais. Eles sâo definidos por Marcuschi (2002, p. 22-23) como "[...] textos materializados que encontramos em nossa vida diária e que apresentam características sociocomunicativas definidas por conteúdos, propriedades funcionais, estilo e composição característica". Dessa forma, os gêneros textuais nâo sâo definidos apenas pela sua estrutura - que náo é estática, mas dinâmica e acompanha as mudanças sociais -, mas também pela sua funçăo na sociedade.

O hipertexto pode ser entendido como "[...] textos năo lineares que oferecem links ou elos de ligaçăo para outros textos, que podem inclusive ser imagens, gráficos, vídeos, animaçôes, sons" (COSCARELLI, 2009, p. 554). Além disso, a autora afirma que os hipertextos năo sâo exclusivos do ambiente digital, como se vê no seguinte fragmento:

Como se pode notar, as definiçóes de hipertexto aplicam-se também a textos que năo estăo em ambiente digital, pois a presença de títulos, subtítulos, índices, pé de página, as redes causais, as cadeias referenciais entre tantos elementos, que marcam a náo linearidade dos elementos do texto, fazem parte de textos de modo geral, náo sendo particularidade dos textos em ambientes digitais (COSCARELLI, 2009, p. 554).

A partir do trecho acima, é possível inferir que a definiçăo de hipertextualidade nâo se restringe ao ambiente digital, pois o texto impresso também oferece elementos que constroem um hipertexto, tais como: referências, notas de rodapé, citaçôes, ilustraçōes, gráficos etc. A diferença entre o hipertexto impresso e o hipertexto digital está, segundo Koch (2009, p. 61), “[...] apenas no suporte e na forma e rapidez do acessamento". Segundo Xavier (2002), o leitor do hipertexto é chamado de hiperleitor. Este, por sua vez, se depara com o hipertexto e constrói sentidos a partir de seus conhecimentos prévios e das informaçōes trazidas no próprio hipertexto. O hiperleitor pode também decidir seguir ou nâo os links disponíveis no hipertexto, construindo, assim, sua própria leitura.

O hipertexto impresso pode também ser construído a partir de elementos multimodais, como gráficos, boxes, ilustraçōes etc. Sendo assim, como afirma Koch (2009, p. 62): "[...] o sentido nâo é construído somente com base no texto central, mas pela combinaçăo de todos esses recursos: portanto, pode-se, perfeitamente, falar, nesse 
caso, da presença de uma multissemiose". Dessa forma, pode-se entender que essa combinaçăo de elementos verbais e năo verbais resulta da multimodalidade presente na construçăo do hipertexto impresso.

Mayer (2001) concebe multimodalidade como:

[...] a apresentaçăo de um material usando palavras e imagens. Por palavras, eu quero dizer um material que é apresentado na forma verbal, tais como textos escritos ou orais. Por imagens, eu me refiro ao material que é apresentado na forma pictórica, tais como os que fazem uso de gráficos estáticos, incluindo ilustraçóes, tabelas, fotos, ou mapas, ou os que usam gráficos dinâmicos, que incluem animaçăo ou vídeo (MAYER, 2001 apud TEIXEIRA, 2008, p. 54).

Teixeira (2008) afirma, baseada em Kress e van Leeuwen (1996 apud TEIXEIRA, 2008), que a análise de um texto multimodal pode levar em conta três metafunçóes: a representacional, a interpessoal e a composicional. A autora enfatiza esta última e afirma que a composiçăo do texto multimodal se dá por meio de três sistemas inter-relacionados:

Valor informativo: a localizaçáo de elementos na página (esquerda e direita, superior e inferior, centro e margem);

Saliência: a capacidade dos elementos atraírem a atençăo do observador em níveis variados através do posicionamento da imagem (frente ou fundo, tamanho, contraste de cor, etc.);

Moldura: a presença ou náo de moldura pode conectar ou desconectar os elementos da imagem (TEIXEIRA, 2008, p. 57 - grifo nosso).

Dos três sistemas elencados acima, destacam-se o valor informativo e a moldura. 0 primeiro sistema diz respeito ao local onde os elementos multimodais estăo dispostos. De acordo com Kress e van Leeuwen (1996), dependendo da localizaçăo da imagem, há um valor informativo diferente: se está à direita do texto verbal, ela representa uma informaçăo nova; se à esquerda, uma informaçáo dada, já conhecida; quando está na parte superior, é uma informaçăo "ideal", quando na parte inferior, uma informaçâo real. Quando está no centro do texto, ele é o núcleo da informaçăo; quando está na margem, ele acrescenta informaçóes ao elemento central.

O segundo sistema moldura trata das linhas que demarcam o espaço de imagens ou ilustraçōes. Segundo Teixeira (2008), elas servem para conectar ou desconectar os elementos multimodais de um texto verbal. Sendo assim, conforme Teixeira (2008), quanto mais forte for a moldura, mais os elementos multimodais estăo desconectados da informaçáo, e quanto mais conectados estăo os elementos, mais se percebe que eles constituem uma unidade de informaçâo coesa.

Entre os hipertextos impressos construídos com os recursos multimodais estăo os livros didáticos. Esses materiais podem ser considerados objetos hipertextuais, pois contêm, em suas páginas, diversos gêneros textuais, ilustraçōes, imagens, ícones, jogos de cores etc. (BARROS-GOMES; SILVA, 2012). Coscarelli (2009) também considera o livro didático como um objeto hipertextual, pois muitos desses materiais possuem páginas com leiuaute semelhante ao das páginas da internet e muitos sites sâo indicados para aprofundamentos de determinados conteúdos. 
Teixeira (2008), ao fazer um estudo de textos multimodais em livros didáticos elenca três princípios da Teoria da Cogniçâo da Aprendizagem Multimídia (TCAM) de Mayer, dos quais destacamos dois:

Princípio Multimedia: os alunos aprendem melhor a partir de palavras e imagens do que de palavras somente; e

Princípio da Contiguidade Espacial: os alunos aprendem melhor quando palavras e imagens correspondentes săo apresentadas próximas do que quando săo apresentadas afastadas na página. (TEIXEIRA, 2008, p. 64-65 - grifo do autor).

Além dos livros didáticos, alguns dicionários escolares direcionados para o Ensino Fundamental - objetos de estudo desta pesquisa - têm sido elaborados com elementos multimodais, com o propósito de esclarecer e contextualizar os conceitos trazidos nos verbetes. Esse modo de organizaçâo dos dicionários escolares permite também concebê-los como objetos hipertextuais. No tópico seguinte, será feita uma discussăo mais profícua sobre esses materiais.

\section{DICIONÁRIOS ESCOLARES}

Os dicionários escolares estâo entre os materiais didáticos que auxiliam no processo de ensino e aprendizagem. Esses compêndios săo destinados aos alunos da educaçăo básica e săo classificados em 4 tipos, segundo o PNLD - Dicionários de 2012, a depender do número de verbetes e das séries a que se destinam (BRASIL, 2012). Sáo eles: tipo 1 - de 500 a 1000 verbetes - destinados aos alunos doprimeiro ano do Ensino Fundamental; tipo 2 - de 3000 a 15000 verbetes - destinados aos alunos do $2^{\circ}$ ao $5^{\circ}$ ano do Ensino Fundamental; tipo 3 - de 19000 a 35000 verbetes - destinados aos alunos do $6^{\circ}$ ao $9^{\circ}$ ano do Ensino Fundamental; e tipo 4 - de 40000 a 100000 verbetes destinados às três séries do Ensino Médio. Este trabalho pretende analisar dicionários do tipo 2.

Cada dicionário escolar tem a sua proposta lexicográfica, ${ }^{165}$ ou seja, seu plano de composiçăo e organizaçăo que leva em conta o público alvo, os critérios de seleçăo e estruturaçâo dos verbetes, o uso ou nâo de ilustraçôes e sua utilizaçâo. Geralmente a proposta lexicográfica vem logo nas páginas iniciais com os seguintes títulos: "apresentaçăo", "como usar este dicionário", "chave do dicionário” etc. (BRASIL, 2012).

Os dicionários do tipo 2 direcionam-se aos alunos do $2^{\circ}$ ao $5^{\circ}$ ano do Ensino Fundamental com o objetivo de consolidar o processo da aprendizagem de leitura e escrita, bem como preparar o aluno para o acesso aos dicionários de tipos seguintes. Eles também se caracterizam, dentre outros, pelos seguintes aspectos: um número limitado de verbetes com foco em um vocabulário básico; utilizam ilustraçōes como estratégia de motivaçăo tanto para a leitura como para complementar os sentidos das palavras; trazem verbetes com estruturas simples e com poucas acepçôes (BRASIL, 2012).

165 Rangel (2011) afirma que "o elemento que, num dicionário escolar, melhor exprime os compromissos explícita e implicitamente assumidos pelo autor entre demandas e princípios pedagógicos, de um lado e, de outro, as exigências decorrentes do rigor lexicográfico, é o que denominamos, no contexto do PNLD, de proposta lexicográfica (ou projeto lexicográfico)" (RANGEL, 2011, p. 53). 
Por trazerem ilustraçóes em suas páginas e informaçōes que ajudam na compreensăo do sentido das palavras, os dicionários do tipo 2 acabam se assemelhando às enciclopédias, podendo ser consideradas minienciclopédias. Pode-se citar como exemplo o caso do verbete quiuí, no dicionário Saraiva Junior, no qual, ao definir como "planta que produz frutas ricas em vitamina $C$, de polpa verde com pequenas sementes pretas e casca marrom coberta de pelos; a fruta dessa planta", o dicionário acrescenta informaçóes dizendo que "a palavra de origem inglesa kiwi refere-se tanto a uma ave que vive na Nova Zelândia quanto a uma fruta, cada vez mais encontrada no Brasil" [...]. É esse caráter enciclopédico desses materiais que se considera o dicionário como um objeto hipertextual, pois, como afirma Lévy (2003 apud FACHINETTO, 2005), em uma enciclopédia pode haver hipertexto.

O caráter enciclopédico de dicionários do tipo 2 auxiliam no ensino mais eficaz da língua, pois possibilita ao aluno um conhecimento vasto, e nâo somente linguístico, de determinados verbetes. No entanto, além do caráter didático dos dicionários, năo se pode negar o caráter prescritivo que essas obras contêm, pois, como afirma Auroux (2009), esses materiais, juntamente com as gramáticas, sâo instrumentos de normatizaçáo da língua.

A partir dos conceitos apresentados sobre texto, hipertexto e multimodalidade em dicionários escolares, é possível compreender os resultados da pesquisa numa seçâo posterior. Mas antes disso, cumpre mencionar o percurso metodológico adotado neste trabalho.

\section{METODOLOGIA}

Esta pesquisa tem caráter bibliográfico, uma vez que analisa dois dicionários escolares do tipo 2, a saber: 1) Saraiva Júnior: dicionário da língua portuguesa ilustrado (2009) e 2) Saraiva infantil de A a Z: dicionário da língua portuguesa ilustrado (2012). A escolha desses dicionários se deu pelo fato de eles serem obras recentes e que possuem o recurso do hipertexto (objeto de estudo).

A pesquisa também possui caráter qualitativo, pois săo descritos alguns aspectos estruturais e formais dos verbetes presentes nos dicionários que, em seguida, sâo relacionados aos hipertextos e aos gêneros textuais.

A coleta e a análise dos dados seguiu as seguintes etapas: primeiramente, fez-se uma descriçăo da proposta lexicográfica de cada dicionário; em seguida, foram selecionadas algumas páginas de cada obra (escolhidas aleatoriamente) para discussáo dos elementos que compóem o hipertexto (imagens e diferentes gêneros textuais); e, por fim, fez-se uma análise comparativa dos dicionários a fim de apontar semelhanças e diferenças entre esses dois dicionários.

A análise dos dados se apresenta no tópico seguinte, seguida das discussóes.

\section{ANÁLISE E DISCUSSÃO DOS DADOS \\ DICIONÁRIO SARAIVA JÚNIOR}

O dicionário Saraiva Júnior: dicionário da língua portuguesa ilustrado é composto por 7.040 verbetes, como informa o próprio dicionário. Nele muitos gêneros textuais sáo utilizados para contextualizar determinada palavra e para acrescentar informaçóes aos 
verbetes. O dicionário contém, segundo as informaçōes da apresentaçăo, 14 trava-línguas, 20 adivinhas, 19 provérbios, 3 poemas, 10 brincadeiras, 11 cantigas de rodas, mais instruçóes práticas em 6 seçōes de "faça você mesmo" e curiosidades em 31 seçóes de "você sabia". Cada um desses gêneros é utilizado para se construir o hipertexto.

Na primeira imagem selecionada, é possível perceber um exemplo de verbetes relacionados a dois desses gêneros:

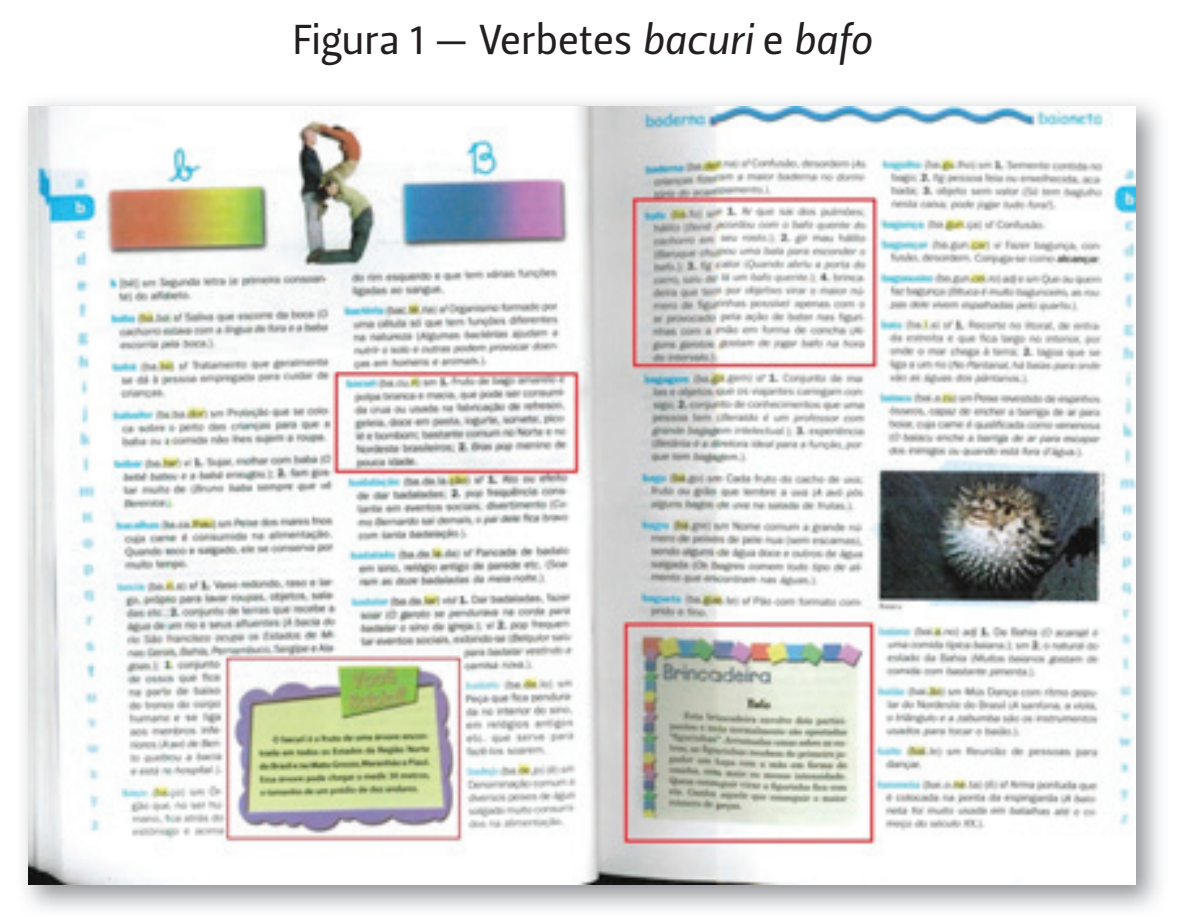

Fonte: Dicionário Saraiva Júnior (2009)

Na imagem acima, destaca-se, os verbetes bacuri e bafo, juntamente com as seçōes Você sabia e Brincadeira. Ao se observar o verbete bacuri, vê-se que săo apresentadas duas acepçôes para explicitar o significado da palavra "bacuri". No entanto, a definiçâo parece nâo contemplar todas as informaçôes que envolvem o termo, o que é de se esperar de um dicionário de pequeno porte, como é o caso deste. Por isso, tem-se a seçáo Você sabia, que informa as regióes onde podem ser encontradas esse fruto e quais as características da árvore que o produz. Tendo em vista essas informaçóes adicionais, esse dicionário se aproxima de uma enciclopédia, cuja característica seria trazer outras informaçôes nâo propriamente linguísticas.

Na parte direita da imagem, destaca-se o verbete bafo, no qual săo apresentados 4 acepçôes. A quarta acepçăo trata-se de uma brincadeira. Essa brincadeira é explicada com mais detalhes no boxe Brincadeira logo na parte inferior da página. O leitor poderá ter mais informaçôes sobre a brincadeira bafo ao se dirigir a esse boxe. Isso mostra, pois, que, nos dois casos, as informaçôes sobre as palavras bacuri e bafo nâo ficam apenas restritas ao gênero verbete, mas săo complementadas com outros boxes utilizados para ilustraçăo.

Nota-se que os boxes săo destacados por meio de molduras, que săo um dos sistemas que compóe a multimodalidade. As molduras, segundo Teixeira (2008), săo usadas para conectar ou desconectar um grupo de elementos visuais num texto multimodal. Sendo assim, 
observa-se que as seçóes Você Sabia e Brincadeira, estăo desconectadas por meio de suas molduras: na primeira seção realçada com a cor lilás, e a segunda, com quadrinhos coloridos.

Outra observaçâo que se faz é que a escolha dos verbetes usada na construçăo do hipertexto parece ser feita de forma aleatória, sem o estabelecimento de critérios.

Na imagem seguinte, é possível visualizar outros casos de hipertextualidade.

Figura 2 - Verbetes batata e trava-língua

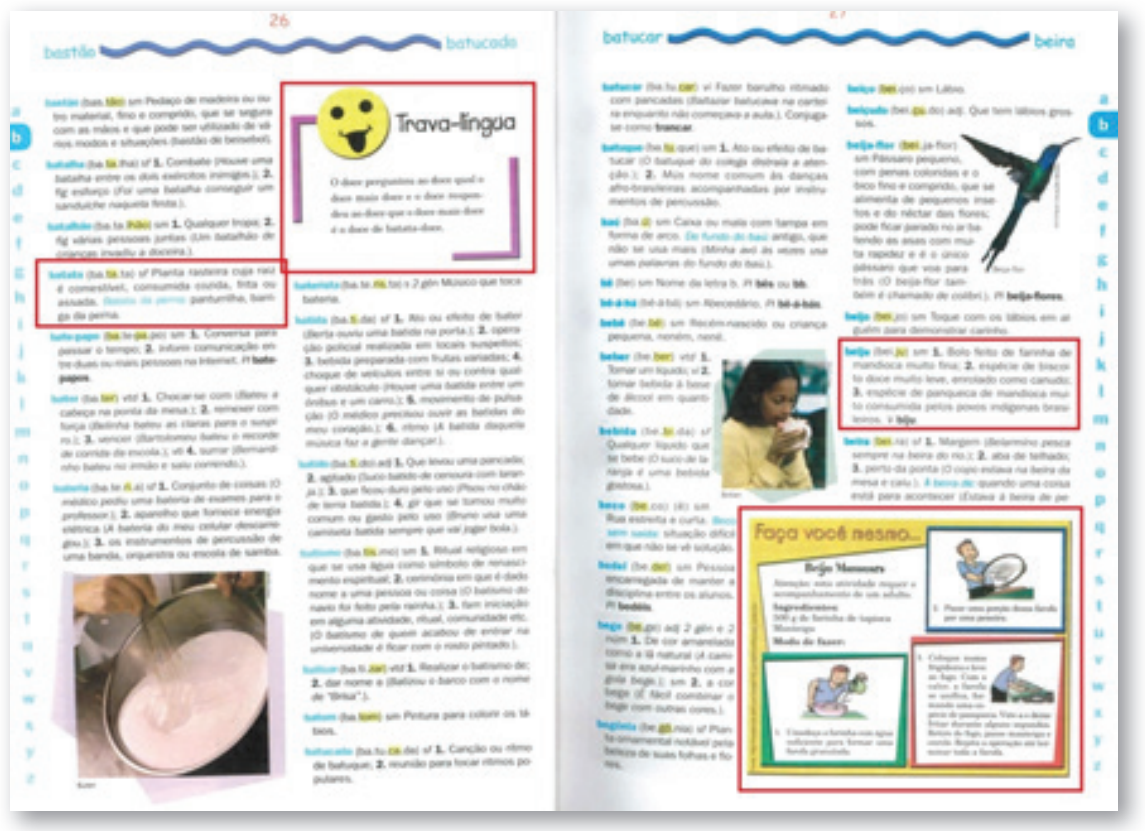

Fonte: Dicionário Saraiva Júnior (2009)

Na parte esquerda da imagem, destaca-se o verbete batata, relacionado à seçâo trava-língua. Neste gênero, trava-língua, a palavra batata é contextualizada. Este dicionário se preocupa em colocar a língua em uso, utilizando a palavra num contexto usual no cotidiano das crianças. Essa relaçăo entre textos pode facilitar o entendimento do significado da palavra.

É importante observar que o termo utilizado no trava-língua nâo é propriamente batata, mas sim batata-doce. 0 que se pode inferir é que o autor do dicionário náo faz distinçăo entre um termo e outro, uma vez que năo há um verbete exclusivo para batata-doce.

Na parte direita da imagem, o destaque é dado ao verbete beiju, relacionado à seçăo Faça você mesmo. Em todas as acepçôes dos verbetes, beiju é tratado como um tipo de comida. Por conta disso, a seçâo Faça você mesmo dá instruçōes detalhadas de como se preparar um beiju. Observa-se que esse boxe tem caráter atitudinal, ou seja, instrui a realizar uma açâo. Nos dois casos analisados, nota-se, mais uma vez, uma relaçăo entre textos, que ajuda o hiperleitor a construir seu próprio conhecimento.

Ainda sobre a figura 2, é possível perceber que as imagens săo utilizadas para ilustrar as páginas, colaborando com a leitura multimodal do dicionário. Elas estấo cada 
vez mais presentes nos textos, como afirma Coscarelli (2009, p. 552): "se antes os textos contavam quase que exclusivamente com a linguagem verbal, agora eles contam também com outras linguagens que podem e devem ser incorporadas a eles".

Retomando o conceito de composiçấo do texto multimodal quanto ao valor informativo (figura 2) nota-se que, no verbete beija-flor, a imagem está do lado direito do texto, representando, assim, uma informaçăo nova. Ou seja, sabe-se o conceito de beija-flor, mas só depois se apresenta sua imagem.

Passa-se, agora, para a análise da figura 3:

Figura 3 - Verbetes boneca e botar

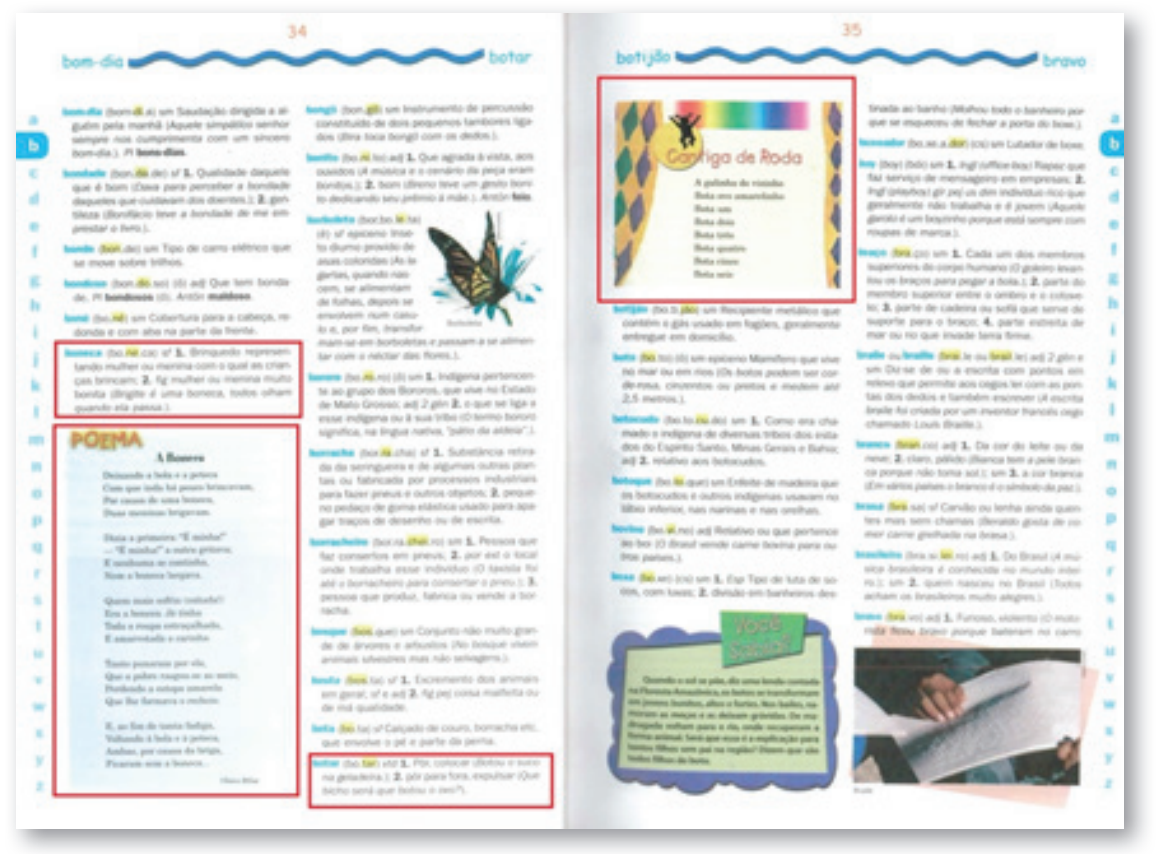

Fonte: Dicionário Saraiva Júnior (2009)

Na imagem acima, no lado esquerdo, destacam-se o verbete boneca e o poema " $\mathrm{A}$ boneca", de Olavo Bilac. Mais uma vez, vê-se a tentativa do dicionário de contextualizar a palavra. A escolha desse gênero também pode ser explicada pelo fato de o autor querer familiarizar os alunos dessa fase de ensino, $2^{\circ}$ ao $5^{\circ}$ ano do Ensino Fundamental, com esses textos. $O$ poema trata de uma cena comum no contexto infantil: a briga por um brinquedo. A escolha da temática também pode ser intencional, uma vez que o dicionário retrata a realidade em que vivem as crianças.

Outro ponto a destacar seria a proximidade entre o verbete boneca e o poema, que, baseado no princípio da Contiguidade Espacial de Mayer (2001 apud TEIXEIRA, 2008), mencionada em tópicos anteriores, facilita a aprendizagem do leitor. Segundo o autor, "[...] os alunos aprendem melhor quando palavras e imagens correspondentes săo apresentadas próximas do que quando săo apresentadas afastadas na página" (TEIXEIRA, 2008, p. 65). 
Outro caso de hipertextualidade ocorre entre o verbete botar e a cantiga de roda. 0 verbo "botar" é explicado no verbete, mas é posto em uso na cantiga de roda, um gênero que também é comum nesse período escolar. Ainda que o verbete e o boxe estejam em páginas diferentes, percebe-se que há também uma contiguidade espacial, assim como no caso mencionado no parágrafo anterior.

A imagem a seguir ilustra outros casos de hipertexto:

Figura 4 - Verbetes galinha e galo

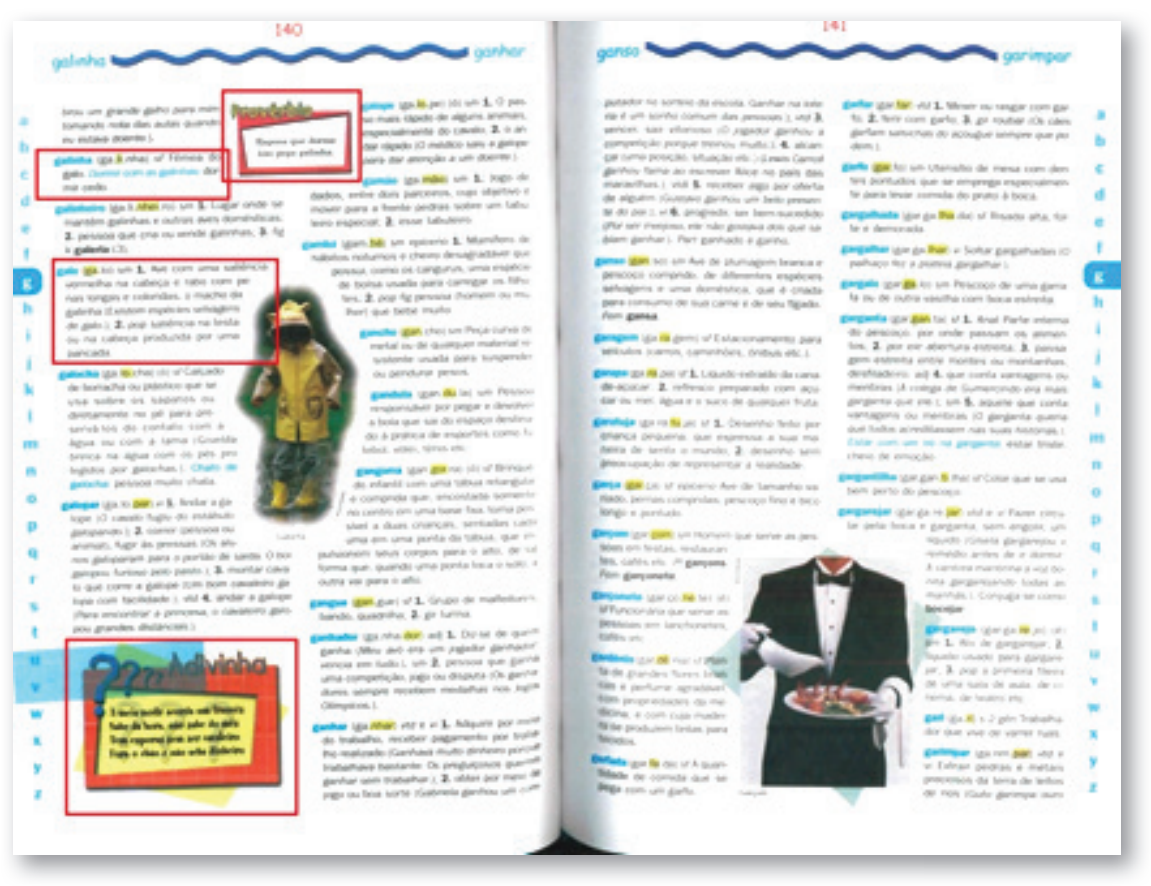

Fonte: Dicionário Saraiva Júnior (2009)

Observando o verbete galinha, nota-se a relaçăo estabelecida com o gênero provérbio, no boxe ao lado do verbete. O provérbio também pôe em uso a palavra galinha e serve para familiarizar o aluno/leitor com esse gênero.

A posiçăo do boxe do provérbio (ao lado do verbete) remete ao valor informativo já mencionado, que, no caso, representa uma informação nova. Além disso, apresenta uma moldura bem forte, propondo uma separação.

No caso do verbete galo, destacado em amarelo, tem-se uma relaçấo năo explícita com o boxe advinha. Isso porque, a palavra "galo" năo aparece na advinha, mas seria a resposta dela. Talvez a relaçấo entre esses dois textos esteja mais voltada para o próprio significado do verbete, pois é por meio dele, ou seja, das pistas dadas na própria advinha ("tem esporas", "fura o chăo") e de outros conhecimentos a respeito do animal que o aluno/leitor possui, é que se poderá obter a resposta da advinha.

Na última imagem desse dicionário percebe-se outro gênero textual utilizado: 


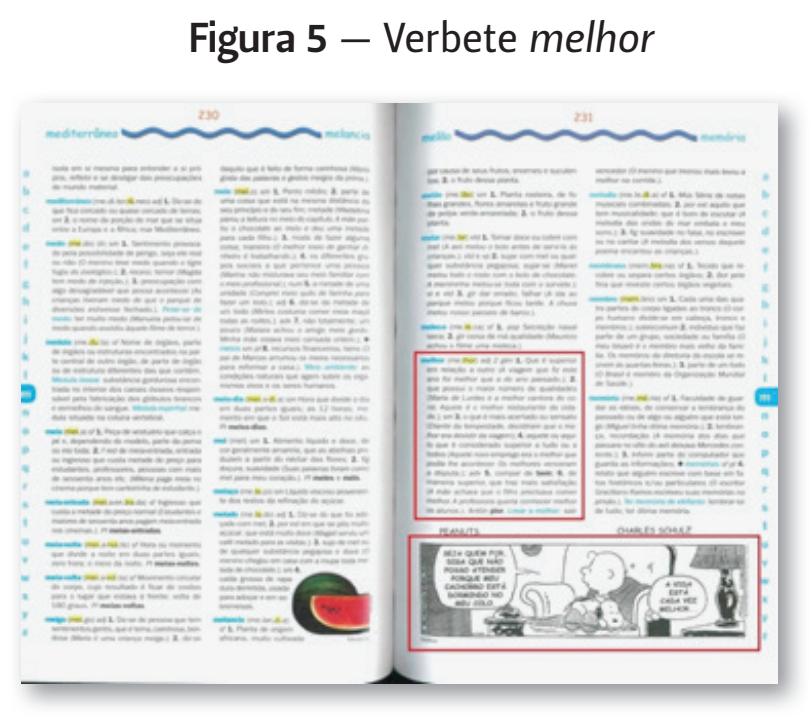

Fonte: Dicionário Saraiva Júnior (2009)

O hipertexto, nesse exemplo, é formado pelo verbete melhor mais a tirinha de Charles Schulz (1990). Nessa tirinha, a palavra melhor é utilizada na fala do segundo balăo. Esse gênero serve, pois, para ilustrar um uso da palavra em questăo. Além disso, mais uma vez, se observa a presença do princípio de contiguidade espacial, pois o verbete e a tirinha estăo próximas uma da outra.

Na seçâo seguinte, passe-se para análise do segundo dicionário.

\section{DICIONÁRIO SARAIVA INFANTIL}

O dicionário Saraiva infantil de A a Z: dicionário da língua portuguesa contém 3.061 verbetes, acompanhados de 300 imagens fotográficas e 200 vinhetas, que ilustram suas páginas. Além disso, o dicionário é composto por 79 tirinhas que também ajudam a contextualizar as palavras-entrada dos verbetes. É através dessas tirinhas que se constrói a hipertextualidade, como se vê na imagem a seguir:

Figura 6 - Verbetes esquecer e esquilo

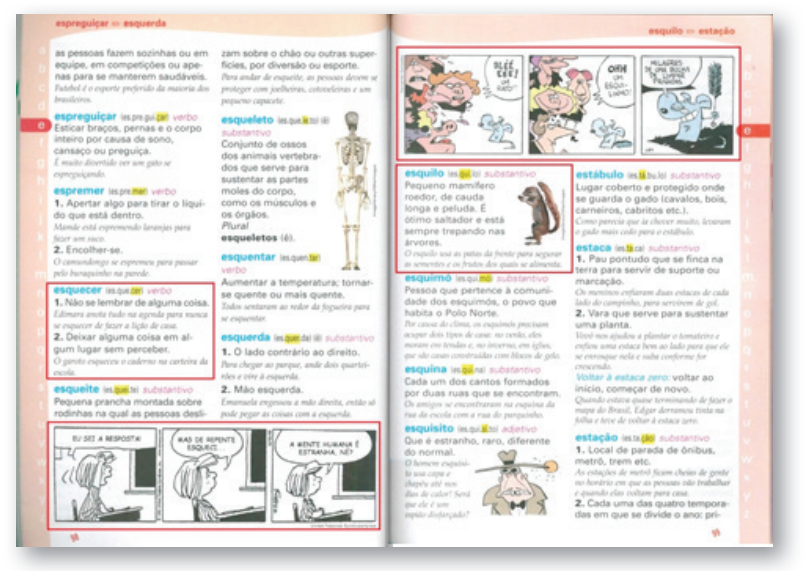

Fonte: Dicionário Saraiva Júnior (2009) 
Na figura 6, é possível notar duas construçōes de hipertexto: a primeira seria, do lado esquerdo, o verbete esquecer relacionado à tirinha do Snoop, logo abaixo, em que a palavra "esquecer" aparece conjugada: "esqueci". A segunda, do lado direito da imagem, está na relaçâo entre o verbete esquilo e a tirinha acima do verbete.

A palavra "esquilo" também é utilizada de forma flexionada: "esquilinho". O uso das palavras flexionadas é interessante para que a criança/leitora compreenda que a palavra pode tomar novas formas em diferentes contextos.

Observa-se ainda que as páginas sâo compostas de imagens que ajudam a ilustrar os verbetes e a construir o sentido do hipertexto, o que prova a presença da multimodalidade na construçâo do texto.

Nesse dicionário, o único gênero textual utilizado é a tirinha. Por causa disso, optou-se por apresentar apenas uma imagem que mostrasse o leiaute desse dicionário, uma vez que nâo há diversidade de gêneros textuais como no dicionário analisado anteriormente.

Diante das análises feitas até aqui, é importante ressaltar que a leitura desses hipertextos nâo se dá, necessariamente, na ordem verbete-ilustraçōes, uma vez que o próprio leitor constrói sua leitura e pode definir a sua sequencialidade. Sendo assim, a leitura pode partir de um dos boxes (advinha, trava-língua, poema etc.) para o verbete ou vice-versa, ou de um boxe para outro. O hiperleitor define sua sequência de leitura, como afirma Storrer: "A leitura de hipertextos é processada parcialmente e numa sequência nem sempre prevista pelo autor, o que ocasiona uma diferença entre a coerência do autor e a do leitor." (STORRER, 2002 apud GOMES, 2007, p. 76). Além disso, nota-se que, nos dois dicionários, năo há um link, ou seja, uma remissăo direta entre o verbete e o elemento multimodal, o qual geralmente se faz com os seguintes recursos: "v. quadro"; "cf. boxe" etc. No entanto, os links podem ser feitos de diferentes formas, como exemplifica Coscarelli (2009, p. 554): “[...] notas de pé-de-página, citaçōes, referências a outros textos e vozes, além de ícones, palavras azuis grifadas, entre outras convençóes para indicar links [...]", o que reforça a tese da autora de que todo texto é um hipertexto.

\section{ANÁLISE COMPARATIVA DOS DICIONÁRIOS E IMPLICAÇÕES PEDAGÓGICAS}

Tomando como base as descriçōes feitas nas seçōes anteriores sobre os dois dicionários, é possível apontar semelhanças e diferenças entre eles quanto à construçâo do hipertexto. Com relaçâo às semelhanças, observa-se que ambos os dicionários ilustram suas páginas com imagens e outros gêneros textuais que se relacionam aos verbetes. Esses gêneros estâo organizados em boxes e dispostos nas páginas dos dicionários. Os gêneros textuais utilizados (trava-línguas, adivinhas, provérbios, poemas, brincadeiras, cantigas de rodas, tirinhas, entre outros), na maioria dos casos, utilizam a palavra de alguns verbetes para contextualizar seu uso. Nâo há um gênero textual para cada verbete, pois apenas algumas palavras săo contempladas. No entanto, os dicionários năo informam o critério de escolha dos verbetes que sâo ilustrados com os gêneros textuais.

Com relaçăo às diferenças, nota-se que os gêneros textuais utilizados no dicionário Saraiva Júnior săo mais diversificados, pois contém trava-línguas, adivinhas, provérbios, poemas, etc., porém o dicionário Saraiva Infantil faz uso apenas do gênero 
tirinha. Essa divergência pode interferir, de alguma forma, no uso do dicionário, pois, sendo o Saraiva Junior mais diversificada em termos de gêneros textuais, a escola, pais e até mesmo as crianças podem preferir utilizá-lo como fonte de consulta. Sendo assim, os dois dicionários utilizam imagens e gêneros textuais na construçâo do hipertexto, contudo um é mais diversificado que o outro quanto aos elementos multimodais.

Tendo em vista que os dois dicionários săo voltados para um público específico alunos das séries iniciais do Ensino Fundamental -, nota-se a sua importância no processo de ensino e aprendizagem de língua materna, sobretudo quanto à aprendizagem da leitura e da escrita. A fazer uso desses materiais, dentro ou fora da sala de aula, o aluno poderá năo somente aprender o significado de uma palavra, mas também conhecer em que contextos essas palavras podem ser utilizadas e, além disso, (re)conhecer diversos gêneros textuais que estăo presentes no dicionário, facilitando, assim, sua aprendizagem de leitura e escrita.

\section{CONSIDERAÇÕES FINAIS}

Este estudo analisou a hipertextualidade em dois dicionários escolares voltados para o público infantil, isto é, para leitores do Ensino Fundamental (do segundo ao quinto ano), com o objetivo principal de identificar recursos utilizados pelos autores, assim como os gêneros textuais que compóem essa construçâo de hipertexto.

A partir da análise feita, observou-se que os recursos utilizados na construçâo do hipertexto foram elementos multimodais, tais como: boxes com diferentes gêneros textuais e imagens ilustrativas. Os gêneros textuais presentes no dicionário Saraiva Júnior sâo provérbios, poemas, advinhas, brincadeiras, trava-línguas, tirinhas, dentre outros. Já no dicionário Saraiva Infantil encontra-se apenas o gênero textual tirinha.

Em relaçăo ao princípio de Contiguidade Espacial de Mayer, presente na construçấo de um texto multimodal, apontado por Teixeira (2008), viu-se que a posiçấo das imagens e das ilustraçôes nos dicionários pode facilitar a aprendizagem dos alunos. Nas páginas analisadas, perceberam-se alguns casos de obediência a esse princípio, em que texto (verbete) e imagem/ilustraçâo estâo próximos um do outro.

A análise feita, neste trabalho, nâo esgota as possibilidades de estudo de textos multimodais como este, pois vários aspectos podem ser explorados. Conclui-se, a priori, que o hipertexto ajuda ao aluno que consulta os dicionários a ter acesso a mais informaçōes, numa mesma página, sem ter que recorrer a outros materiais. 


\section{REFERÊNCIAS}

AUROUX, S. A revoluçâo tecnologia da gramatizaçăo. 2. ed. Campinas: EdUnicamp, 2009. BARROS-GOMES, J. S.; SILVA, J. O. Textualizaçăo do discurso: o livro didático como hipertexto. Revista Encontros de Vista, jul/dez, 2012.

BRASIL. Ministério da Educaçăo. Secretaria de Educaçăo Básica. Com direito à palavra: dicionários em sala de aula / [elaboraçăo Egon Rangel]. - Brasília: Ministério da Educaçăo, Secretaria de Educaçâo Básica, 2012.

COSCARELLI, C. V. Textos e hipertextos: procurando o equilíbrio. Linguagem em (Discurso), Palhoça, SC, v. 9, n. 3, pp. 549-564, set/dez, 2009.

FACHINETTO, E. A. O hipertexto e as práticas de leitura. Revista Letra Magna: Revista Eletrônica de Divulgaçâo Científica em Língua Portuguesa, Linguística e Literatura Ano 02, n.03 - 20 Semestre de 2005.

FÁVERO, L. L.; KOCH, I. G. V. Linguística textual: uma introduçăo. 9. ed. Săo Paulo: Cortez, 2008.

GOMES, L. F. Hipertextos multimodais: o percurso de apropriaçăo de uma modalidade com fins pedagógicos. 2007. 214 f. Tese (Doutorado) - Instituto de Estudos da Linguagem Universidade Estadual d e Campinas. Campinas: SP, 2007.

KOCH, I. G. V. Desvendando os segredos do texto. 6. ed. Sáo Paulo: Cortez, 2009.

MARCUSCHI, L. A. Gêneros textuais: definiçāo e funcionalidade. In: DIONISIO, A. P. et al. (Orgs.). Gêneros textuais \& ensino. Rio de Janeiro: Lucerna, 2002, pp. 19-36.

RANGEL, E. O.; BAGNO, M. Dicionários em sala de aula. Brasília: Ministério da Educaçăo. Secretaria de Educaçăo Básica, 2006.

Dicionários escolares e políticas públicas em educaçăo: a relevância da proposta lexicográfica.In: CARVALHO, O. L. S.; BAGNO, M. Dicionários escolares: políticas, formas e usos. Săo Paulo: Parábola, 2011.

SARAIVA INFANTIL DE A A Z: dicionário da língua portuguesa ilustrado. 3. ed. ampl. Sáo Paulo: Saraiva, 2012.

SARAIVA JÚNIOR: dicionário de língua portuguesa ilustrado. 3. ed. Sáo Paulo: Saraiva, 2009.

TEIXEIRA, C. H. E. T. A multimodalidade do gênero livro didático de língua inglesa: imagem, texto e funçâo. 2008. 146f. Dissertaçăo (Mestrado em Letras). INFORMAR FACULDADE. Pontifícia Universidade Católica do Rio de Janeiro, Rio de Janeiro, 2011.

XAVIER, A. C. S. Hipertexto na sociedade da informaçăo: a constituiçăo do modo de enunciaçăo digital. 2002. 214 f. Tese (Doutorado). Instituto de Estudos da Linguagem. Universidade Estadual de Campinas - Campinas, SP, 2002. 